\title{
Budoucnost v minulosti
}

\author{
Prof. PhDr. Petr Jemelka, Dr.
}

\section{Stroje a lidé - optimismus i obavy}

Stroje v tradičním pojetí konají tupě mechanicky, sériově opakují stále tytéž úkony ve stejné kvalitě. Potud je vše v pořádku. Stroje nevykonávají rozhodnutí. To jim nepř́ísluší. K rozhodování nejsou určeny a nemají ani patřičné struktury, které by jim to umožňovaly. Potud je opět vše v pořádku. Stroj byl vytvořen a chápán jako alternativa dělníka, která je mnohonásobně výkonnější, rychlejší a přesnější než dělník živý. Je ovšem dělníkem nekvalifikovaným, koná jen jednoduché úkony. Stroj proto vyžaduje jistý servis jak v údržbě, tak i v př́ípravě pracovních operací, není však limitován biologickými a psychickými mezemi možností dělníka živého (člověka či zvířete).

V pozitivní (resp. pozitivistické) optimistické etapě rozvoje strojové techniky se zdálo, že je nastoupena cesta pokroku ke světlé budoucnosti, v níž vědecké myšlení a jeho technická a technologická aplikace vyřeší každý možný problém civilizačního rozvoje. Ani problém surovin nebyl neřešitelným zádrhelem; stále ještě bylo na světě dost necivilizovaných oblastí, které bude v budoucnu možno kolonizovat a exploatovat.

V těchto kontextech „století páry“ se zrodil i nový literární žánr - specifická podoba optimistické technologické utopie, tak jak ji známe z románů J. Verna. Lze říci, že jeho knihy jsou kvintesencí pozitivismu včetně osvětové role, nebot' se v nich dozvídáme, jak se co dělá (viz Tajuplný ostrov).

Po čase se však objevily i jiné úvahy, nepochybně inspirované také děním v sociální realitě. Tou začalo obcházet jisté strašidlo. Nezapomeňme, že selské bouře byly již v této době dávnou a pozapomenutou minulostí, kterou potlačila kombinace násilí, vnitřní nesvornosti a náboženských ústupků. Na rozdíl od sedláčků však rychle a bez tradic zrozený průmyslový proletariát neměl $\mathrm{k}$ dispozici žádnou kompenzaci v podobě svátku voraček. ${ }^{1}$ Temné hučení zezdola hrozivě sílilo. A také ona zmíněná rodící se nová úvaha si začala pohrávat s představou vzpoury - dělníků neživých. Latentně se v ní vzbudila obava z toho, že by stroje mohly nabýt schopnosti rozhodování. Že další technický rozvoj vytvoří mechanické struktury, schopné převzít tuto doposud výsostně lidskou funkci. Její podoba by však nutně nabyla ne-lidské dimenze jak kvantitativní (množství, síla a mechanická odolnost strojů), tak i kvalitativní. Lidskému zájmu dělníka koneckonců lze porozumět; jaký by však byl zájem a tužby stroje?

Vzpoura strojů je tak představou, která se objevuje již v mechanické fázi, není spjata až s obdobím představ o možnostech aplikované kybernetiky. ${ }^{2}$ Utopický žánr se tak mění, vzdává se v mnohém svého původního optimismu a obnovuje původní „frankensteinovský““

\footnotetext{
${ }^{1}$ Př̀i tomto svátku zemědělských dělníků se nahromaděná frustrace vybila neškodně v jednom dnu vyměněných rolí a jako investice postačila trocha piva.

${ }^{2}$ Připomenout pamětníkům můžeme slavný český komiks Vzpoura mozků z časopisu ABC.
} 
motiv, varující člověka před př́liiš odvážnými výboji. ${ }^{3}$ U nás lze odkázat na klasiku - RUR (i jako inspiraci pro další autory - A. Tolstoj, R. Rolland aj.). Odtud není již daleko k anti-utopii, odkazující na problém odcizení a manipulace totalitním režimem (klasický film Metropolis, Zamjatin, Orwell aj.).

Stroj těchto vizí je zkrátka něco jako velké zvíře, které nechápe a které koneckonců ani my nechápeme. Zviŕre, které se může začít chovat zcela nevyzpytatelně a které může křehkou formu lidského těla velmi snadno rozbít. Mimo tohoto strachu i jistého respektu bylo vnímání strojů zatím stále provázeno také okouzlením. Okouzlení technika a vynálezce hraničí s posedlostí, s touhou po vyřešení úkolu i po dokonalosti realizace. Okouzlení diváka - jak se to leskne, jak to hezky běží a vrčí, i když vlastně nevím, k čemu to je. Okouzlení uživatele že to funguje, že zvládám stroj řídit, že jsem schopen ho opravit. To vše bylo na technice této fáze fascinující.

Staré stroje navíc představovaly (dík i navzdory nutnosti být především funkční) i estetickou výzvu. Od ornamentální košatosti „belle époque“ ke strohé eleganci funkcionalismu a smělé představivosti a překvapivým designovým výbojům futuristických vizí jsou vždy stroje významnou součástí estetického vnímání a hodnocení.

V naší době je již několik desetiletí projevem takto technikou motivovaného uměleckého směřování i tzv. retrofuturismus. Jeho východiskem jsou původní archaické představy o podobě budoucnosti (tzv. utopické romány, urbanistické či dopravní projekty atd.), které jsou přetvářeny do svébytné podoby umělecké tvorby, aplikací do užitého umění a ovšem i kýče. V každém př́padě ovšem retrofuturismus představuje jistou rehabilitaci a ocenění projektů opuštěných a zdánlivě zapomenutých, která se navíc někdy pojí i s úspěšným mimouměleckým realizačním návratem. ${ }^{4}$ Nejde tedy jen o samoúčelnou nostalgii a staromilství, ale o plnohodnotnou tvořivost uměleckou i technickou.

\section{Šance pro budoucnost?}

Právě tyto aspekty soudobé retrofuturistické módní vlny se staly i podnětem k následující prosté úvaze, která dala i název tomuto př́íspěvku.

Nosným motivem našeho dnešního setkání jsou podněty výchozího zdroje - sborníku Budoucnost technické civilizace. Jde o pozoruhodné dobové svědectví o pokusech uchopit ty otázky, které dnes označujeme za globální problémy z různých úhlů a z hlediska rozličných teoretických disciplin. Je zde obsažena i esej významného filosofa B. Russela Věda a strojová civilizace. ${ }^{5} \mathrm{~V}$ jejím závěru autor vyjadřuje jistou obavu $\mathrm{z}$ budoucího vývoje. I když nesdílím s Russelem naturalistické (eugenické) názory, musím uznat nepochybnou oprávněnost jeho varování před ,ředěním“ (čili úpadkem) inteligence lidské populace v souvislosti s rostoucími

\footnotetext{
${ }^{3}$ Pověsti o Golemovi jsou ještě starším předobrazem, ovšem vystavěným na náboženském zákazu jistých člověku nepříslušejících pokusů.

${ }^{4}$ Jako konkrétní př́klad můžeme poukázat na soudobý poměrně běžný reálný provoz horkovzdušných balónů. Přitom se v jisté době zdálo, že jde o zcela slepou uličku ve vývoji letecké techniky - např. je takto skeptický český filosof a historik techniky A. A. Hoch (1936, s. 124).

${ }^{5}$ In Beard (1933, s. 67-85).
} 
nároky na ř́zení a údržbu vyspělých technologií. ${ }^{6}$ Podle Russela i podle některých dnešních průzkumů lidstvo hloupne a v budoucnu může hrozit, že nebude dostatek kvalifikovaných odborníků pro udržení chodu složitých technologických struktur. ${ }^{7}$ Přitom lze mít za to, že jistý nezanedbatelný podíl na poklesu intelektuálních schopností má i rozvoj moderní technologie (zejm. univerzálné zapojení počítačů). Klesající schopnost porozumět psanému textu či logicky konzistentně a gramaticky správně psát jsou př́íklady tohoto trendu. Reakcí jsou následně požadavky na zjednodušení gramatiky či na primitivizaci výuky psaní, ale i vydávání „nejlepšího světového čtení v citlivé redakční úpravě“ (Reader's Digest) a podobných literárních masakrů.

Průkopníci tohoto rádoby progresu zapomínají na nezpochybnitelnou spojitost mezi jemnou motorikou a rozvojem mozkových struktur, pojících se již přímo s tím, co nazýváme inteligencí ve smyslu porozumění logice reality.

Naopak klasická mechanická podoba techniky tato rizika zřejmě neprohlubuje. Mechanický stroj je systémem logicky uspořádaných makroskopických částí. Jako takový je př́stupný lidskému smyslovému vnímání a je i kauzálně uchopitelný ve své strukturaci a funkčnosti. Jeho obsluha toto porozumění rozvíjí, jeho opravy vyžadují i jistou manuální zručnost, protože nejsou jen výměnou vadného „bloku.“ Souhrnně snad lze říci, že mechanická úroveň techniky (včetně užitých materiálů) tedy odpovídá „lidské přirozenosti“a a je schopna přispívat $\mathrm{k}$ rozvoji lidských tělesných i intelektových schopností. Technologie digitální lidskou přirozenost nahrazuje.

Již zmíněné okouzlení starou technikou proto nechápejme jen jako výraz módní vlny retro-nostalgie, ale lze je vnímat jako součást cesty k zachování budoucnosti, v níž lze člověku žít (nikoliv jen přežívat v ,matrixové“ simulaci).

Zmínili jsme zde oblibu retrofuturistických motivů. Zkoumání starých představ o možných podobách lidské budoucnosti může přinášet mnoho užitku. Poučení z odhalené naivity, varování před dehumanizujícími verzemi řešení problémů, inspiraci projektantům i estetické uspokojení.

Za jistou část retrofuturistického uměleckého proudu je označován také tzv. steampunk. Není to zcela přsesné, nebot' steampunk si vlastně nepohrává s vizemi budoucnosti, ale spíše se zaměřuje na modelování paralelní historické „přítomnosti“ - tedy vrací se do minulosti a nabízí její alternativní obraz. ${ }^{8}$ Ten je založen na maximalizovaném (ba hypertrofovaném) potenciálu původní (vesměs mechanické) úrovně techniky.

Celkově tedy steampunk představuje značně nostalgickou, ale i velmi barvitou podobu návratu k „belle epoque,“ ba i před tuto dobu - do viktoriánské éry. To byla doba, kdy stroje již přestaly být kuriózními prototypy či zábavnými hř́ičkami. Převzaly již definitivně zásadní

\footnotetext{
${ }^{6}$ Tamtéž, s. 83.

${ }^{7} \mathrm{~V}$ komediální podobě je katastrofická vize tohoto regresu zpracována ve filmu Idiocracy (v české verzi $\mathrm{z}$ nepochopitelných důvodů pod názvem Absurdistán - což vede k záměně se stejnojmenným německým filmem).

${ }^{8}$ Koneckonců ani romány J. Verna nejsou zasazeny do budoucnosti (stejně tak u nás dobrodružné př́iběhy Troskovy či Běhounkovy).
} 
civilizační produkční roli i se všemi hrůzami dopadů této kompetiční etapy dějin na člověka. Přitom ale tvůrci strojů (a také staveb $\mathrm{k}$ nim se vážících atd.) nepřestali respektovat dobový vkus, ba jej i spoluutvářeli (Palm House v botanické zahradě v Kew jako první stavba z oceli a skla, Eiffelova věž, Petřínská rozhledna ...).

Právě z této podoby estetického cítění nejhlouběji čerpá steampunk. Zasahuje snad do všech oblastí užitého umění a zvládá promítat svůj designový kánon i do velmi př̌kvapivých zcela soudobých souvislostí. ${ }^{9} \mathrm{~S}$ tím se pojí i velmi cenný moment - steampunk je mimo komerčně vděčného zdroje i inspirací mocné vlny tvưrčích aktivit. Toto v dobrém slova smyslu kutilství má (oproti éře časopisu Udělej si sám či návodům z Receptáře) výrazný estetický rozměr. Tato módní vlna je tak výchovně či kultivačně naplněna velkým potenciálem. V utopické vizi třeba bude méně dětí chtít „dělat na počítači“ a raději si zvolí řemeslo (ale ne jen ,sádrokarton“), aby jednou dokázaly něco konkrétního udělat vlastníma rukama a hlavou na profesionální úrovni. ${ }^{10}$

\section{Romantika na konec}

I kdyby byly původní reálné mechanismy a jejich funkce nahrazeny virtuální realitou a 3D tiskárnami, jeden moment snad přežije. Krása klasického stroje, krása jeho mechanického těla. Plast nebo virtuální simulace nikdy nemají patinu a tedy věrohodnost. Mohou ji opět jen simulovat.

Retro-styl čelí ušmudlanosti a úpadku estetiky opravdovostí původního materiálu a poctivostí zpracování. A to neplatí jen pro řemeslné výrobky. Se steampunkem se vrací romantická krása solidního dobrodružného př́iběhu ${ }^{11}$, v němž je stroj důležitým prvkem i motivem. „Verneovky“ přetavené do nové kvality Zemanových i pozdějších filmů jsou postmoderní výzvou, oslovují i kultivují, inspirují děti i dospělé stejně dobře jako knihy, ilustrace, modely a hračky. Komu se snad nelíbí viktoriánská éra, najde modernější inspiraci v dieselpunku, vystavěném na estetice první třetiny století dvacátého a na romantice př́iběhů hrdinů prvních klasických komiksů. Vzducholodě, dvojplošníky, kožené kukly, letecké brýle a aerodynamické karosérie. Ze steampunku zvláštně voní kouř lokomotiv, opium a parfémy, $\mathrm{z}$ dieselpunku kůže, benzín a pudr. Tu se lekáme Jacka Rozparovače a úkladů prof. Moryartyho, tam se můžeme bát velkých havárií a jednotných šiků pochodujících vyleštěných holínek. Chtě nechtě se potkáváme s historií.

Nevzdávejme se minulosti jako navždy překonané. Ostatně pro oblast techniky nepochybně platí, že se v jejím vývoji volně mísí staré i nové principy v pozoruhodných kombinacích. Její evoluce nezná takové hranice a omezení jako evoluce živá. Závisí jen na smělosti a fantazii tvůrců - a bohužel i na ekonomické, politické, sociální a environmentální realitě. Technický vývoj není samospasitelným řešením lidských problémů. Mưže však být pro tato řešení užitečným nástrojem stejně jako může být prostředkem ke zničení světa.

\footnotetext{
${ }^{9}$ Např. notebook v mramoru a mosazi...

${ }^{10} \mathrm{Na}$ tomto motivu jsou vystavěny např. reklamy na Velkopopovického kozla.

${ }^{11}$ Vůbec přitom nemusí vadit, že jde o tzv. triviální literaturu.
} 


\section{Literatura:}

Hoch, A. A., Vynálezy které změnily svět. Praha 1936.

Beard, Ch., A. (ed.), Budoucnost strojové civilisace. Praha 1933.

http://dieselpunksencyclopedia.wordpress.com/

http://sf-encyclopedia.co.uk/fe.php?nm=steampunk
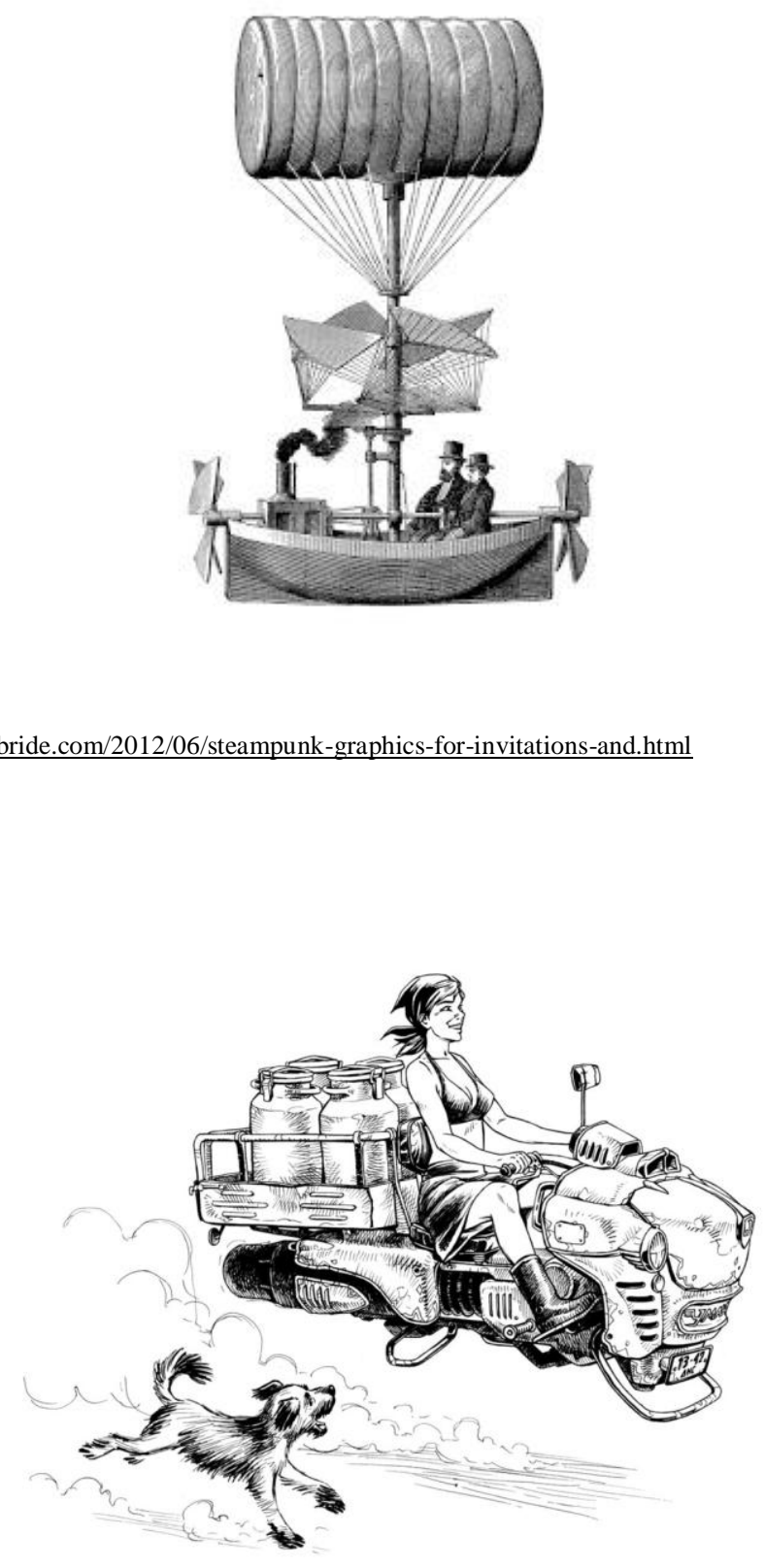